\title{
Endothelial Transcription Factor GATA-2
}

National Cancer Institute

\section{Source}

National Cancer Institute. Endothelial Transcription Factor GATA-2. NCI Thesaurus. Code C97554.

Endothelial transcription factor GATA-2 (480 aa, $~ 51 \mathrm{kDa}$ ) is encoded by the human GATA2 gene. This protein is involved in both sequence-specific DNA binding and the modulation of transcription. 